\title{
Research Article \\ Assessing the Effectiveness of Foreign AID and Its Mobilization in Nepal
}

${ }^{1}$ Khom Raj Kharel, ${ }^{2}$ Dipak Bahadur Adhikari*, ${ }^{3}$ Ramesh Bahadur Khadka Associate Professor of Economics, Tribhuvan University

${ }^{2}$ Lecturer of Economics, Tribhuvan University

${ }^{3}$ Lecturer of Economics, Janapriya Multiple Campus, Pokhara

*Corresponding Author: dbadhikari10@gmail.com

Article History

Received 23 April 2021

Revised 01 October 2021

Accepted 10 December 2021

\begin{abstract}
This paper has focused on the effectiveness of foreign aid for economic progress of developing nations with emphasis of Nepal. Nepal has the momentum of uplifting developing nations from the least developed countries by accepting foreign aid through the effective mobilization. This study has been conducted by using the historical data over the period of 1992/93-2019/20. The paper has argued that the concept of granting and withholding of foreign support useful resources changed into and nevertheless getting mobilization to steer the macroeconomic policies of growing developing nations. The paper has argued that foreign aid effectiveness reflected in terms of improving people's livelihood with better status. To measure the effectiveness of the foreign aid, the simple statistical tools have been applied. The present study has found that foreign aid granted to government of Nepal and enhanced great effort in the economy but it changed into positive prerequisites with the aid of using donors and debt which impacted negatively to its motive ensuing Nepal's government turning into depending on foreign aid effectiveness mobilizations.
\end{abstract}

Keywords: Contribution, effectiveness, evolution, foreign aid, Nepal, real GDP

\section{INTRODUCTION}

Foreign aid includes grants and loans with one government or multilateral organizations which provide to a growing phase of economic progress and improvement of welfare. The

(C) The Author, published by JRCC, Janapriya Multiple Campus. 
foreign assistance has to be granted on concessional terms, which in case of a mortgage approach of a grant, the facts on legit improvement help additionally consist of technical cooperation (CBO, 1997). Foreign aid resource has been assumed to be the maximum essential supply of outside finance for growing nations to fulfill the fundamental human needs, infrastructure improvement according with country building. Bhattarai (2007) highlighted that till the mid1960 s, Nepal became nearly completely depending on foreign support for all its improvement assignment so it's far a useful resource structured United States. The overseas useful resource became channeled thru capital transfers and funding initiatives to triumph over the capital scarcity which hindered improvement in lots of nations. Various boom orientated useful resource applications had been initiated along with poverty alleviation, army improvement and academic elevation (Paul,2006).

Nepal is a beneficiary of foreign aid and has been a member of the Colombo Plan for Cooperative, Economic, and Social Development in Asia and the Pacific since 1952. Nepal has received foreign support in the form of grants throughout the 1950s decades, with the majority of aid going to transportation, agriculture, power production, and infrastructure, although other areas such as communications, industry, education, and health were targeted for aid mobilization. More over a third of all funds were given to India and the United States. Similarly, the United Kingdom, Switzerland, Australia, Japan, and New Zealand participated in support programs to varying degrees, while the United Nations [UN] offered little technical assistance.

Nepalese government has been directing the foreign support and aid as per the guidelines of ministry of finance and national planning commission with the basis of national priorities and policies. The foreign aid used in projects and programs is received in various forms based on the principle of competitive advantage. Grants are mobilized primarily in the areas of rural infrastructure development, health, education, drinking water, sanitation, sanitation and other social sectors, and human development.

Aid mobilization had given as the top priority for Nepal's government in the areas of agricultural development and climate change. Nepalese government gets both concessional and non-concessional loans from bilateral and multilateral development partners, but favors concessional loans in most circumstances. In terms of foreign aid, the Nepalese government has accepted technical help, consultant mobilization, and external volunteer mobilization. In Nepal's growth, foreign aid continues to play an essential role. Apart from its role in maintaining public investment, foreign aid appears to be vital in accomplishing the government's five- 
year poverty reduction goals, which include generating high and sustained rates of economic development and supporting critical sectoral programs and activities (Ministry of Finance [MOF], 2002).

In Nepal, formal development assistance and development cooperation have been channeled for more than six decades. Until the late 1980s, foreign aid remained the primary source of development funding. In the First Five Year Plan, foreign aid covered the entire development budget (1956-61). Up to the 1990s, foreign aid had contributed more than 75\% of capital spending in budget formulation in every year. The foreign support had been used for channelizing into the national predominantly in the form of grants whereas it was loans which proved dominant in the forthcoming years. The share of foreign aid has gradually reduced with the improvement in internal resources mobilization after 1980s. After 2000s, the ratio of foreign aid to the annual budget range from 20-30 percent (MOF, 2017).

Foreign aid has been taken as the one of the fundamental bases of government expenditure to the developing nations. The growth trends of foreign aid inflow have been significantly increasing in terms of debt and grants as well as assistance since 1990s. The proportions of debt ratio of debt trends have found greater than grants whereas mobilization of foreign aid found less than 50 percent in comparison to approved. The ultimate goal of that research has to analyze the contribution of foreign aid in the context of Nepal's economy. More preciously, it aims to study effectiveness of mobilization of foreign aid with reference to GDP and government expenditure.

The available foreign aid in the developing countries has been remarked as the significant financial sources to induce economic growth and progress. There has been found dual impact foreign aid in the economy. Numbers of studies of aid effectiveness have failed to arrive a consensus where some studies found foreign aid adversely affect domestic resource mobilization. Some studies found a positive impact on economic growth (Murshed \& Khanaum, 2014).

Hannemann and Schneider (1988) focused on the determinants of bilateral and multilateral aid given to developing countries. They tried to model the allocation process of different types of foreign aid and derive testable hypothesizes using the public choice framework. Bilateral aid commitments were partly influenced by recipients, need and political and military aspects which also accounted for the allocation of multilateral aid by UN agencies and other international organizations. The researchers proposed that a greater focus to be placed on a more rigorous and extensive understanding of the interests, incentives structures, 
and limitations in the international politico-economic process.

Gounder (2003) has empirically evaluated the effect of foreign aid for promoting economic progress with directional of causality between economic growth and foreign aid in the Solomon Islands. The empirical outcomes display that volume of foreign aid contributes undoubtedly to the Solomon Islands financial increase. The effective contribution of mobilization of foreign aid positive contributed in the economy. The positive contribution of foreign aid suggested that aid conditionality effectively delivers benefits that contribute to growth. The aid funds were utilized more effectively in development projects which meets the goals of development assistance, improves the standard of living of the people who were otherwise continue to lack of basic needs and not better their conditions to improve their economic positions. The direction of causality test indicated positive and statistically significant values that show patterns of causality in both the directions.

Economic integration and subsidiarity, as analyzed by Chowdhury and Garonna (2007), offers the circumstances for government development aid to achieve greater rates of economic growth on a long-term basis. The study found that development of assistance was at the heart of a new bipolarize that was evident in the both the donor and the recipient countries. There was a growing perception in the recipient countries that donors were not sharing opportunities and wealth in supporting economic growth and fighting poverty in the developing world. They suggested that the need for a political trust, strategic purpose, institutional support and bold reform initiatives to supplement the receipt of development assistance could not over emphasize.

Werker, Ahmed and Cohen (2009) examined the impact of the foreign aid in the aid recipient countries by applying the natural experiment method. As per the study, they investigated that how the foreign could spend for tracking its short-term impact of aggregate demand, national accounts and balance of payments of the nations. They had also remarked that aid has not measurable impact on economic growth and prices however it affected most of components of national income accounts.

Aime (2010) argues that beneficiaries have continued to show a decline in economic performance for 50 years after the increase in Official Development Assistance (ODA). The situation raised many questions about the relevance of aid scale-up in the context of poverty reduction and fueled debate about the effectiveness of aid. It is difficult to determine if ODA was the sole responsibility for failure or success in the recipient country. There are several determinants of economic growth, many of which affect development performance. However, 
donors cannot be fully or independently responsible for assistance from official donors. Donors, on the other hand, are misleading in focusing solely on donor countries when trying to improve the effectiveness of aid.

The foreign aid has been assumed to be effectively mobilized to get the maximum benefits to the nation and people. It has been noted that aid should more effective while mobilized to the poor people and cost effective. The real aid could empower to the poor people and ensures their rights as well as it reduces poverty and income inequality by supporting to the smallholder farmers, empowering women or building schools, supporting tax systems, better governance or economic development.

De Renzio (2016) working paper has argued that the future of development assistance and the realization of its potential impact on poverty and development, depends crucially on the efforts donor governments and their aid agencies would spend it the coming years to address two interrelated accountability dilemmas which lie at the heart of donor behaviors. For this, first, aid accountability should be shifted from domestic actors in the donor countries to the beneficiaries of foreign aid in recipient countries in order to better respond to their needs and priorities and second, it should be reconciled its focus on short term development impact with the long term institution building needed to ensure development impact for sustainable.

As per Action Aid (2011), Nepal has made impressive progress against poverty showing the most improvement of any country on the Human Development Index between 1980-2010. More than 4 out of 5 children were found in schools, girls as well as boys. Nepal was on track to meet the health MDGs. Gulrajani and Calleja (2019) have suggested that the three principles of national interest of aid priority. The extent to which aid has allocated to countries that address critical development needs and vulnerabilities, channels and activities that facilitate and support global cooperation and maximize every opportunity to achieve development impact rather than a short-sighted domestic return.

Pradhan and Phuyal (2020) have tested the relations of foreign aid on economic growth and progress in Nepal where they found a positive influence of foreign aid on GDP. They recommended that government policy have to mobilize the foreign aid in the areas of productive sectors and human capital development. Karki and Pappas (2020) pointed that foreign aid could serve as a major source fund in the developing nations like Nepal. The results showed that the foreign aid independently does not mean adequate for economic progress and growth. The study has found negative impact of aid on per capita real GDP in the short run because of ineffective on monitoring, problems related to aid management and conditionality. 
Development economics does not identify the independent existence of foreign aid theories. The empirical literature does not provide a clear cut about the effectiveness of foreign aid in increasing economic growth. Though, most of researchers had suggested a positive relationship between foreign aid and economic growth. There have been conducted different studies toward the foreign aid and its effectiveness in different country contest, however there has not been conducted a comprehensive study toward the foreign aid effectiveness with reference to Nepal. This study has examined the evolution and effectiveness of foreign aid of Nepal.

Development economic science doesn't determine the freelance existence of foreign aid theories. The empirical literature does not enhance a clear picture regarding the effectiveness of foreign aid in increasing economic growth and progress. Though, most of researchers had recommended that there have to be a positive relationship between foreign aid and economic growth. There have been conducted different studies toward the foreign aid and its effectiveness in various country contest, but there has not been conducted a comprehensive study toward the foreign aid effectiveness with respect to Nepal. This study has examined the evolution and effectiveness of foreign aid of Nepal

\section{DATA AND METHODS}

This study has basically analyzed the evolution and effectiveness of foreign aid on Nepalese economy over the period of 1992-2019. Review of foreign aid effectiveness is being done to see the effectiveness of foreign aid. The analytical approach is applied to assess the evolution of foreign aid of Nepal. The effectiveness of foreign aid is based on aid policy and political matter. The policy and political status heavily influence the effectiveness of foreign aid.

The present study is based on secondary data under which the descriptive and analytical research design has been applied. For justifying the descriptive research design, the simple statistical tools have been used as required in the respected areas. For measuring the effectiveness of foreign aid, the simple regression model has also been applied.

The analysis and discussion have been based in published source of secondary data such as Economic Surveys published by MOF and Quarterly Economic Bulletin published by NRB. The effectiveness of foreign aid is measured in terms of impact on GDP and government expenditure. Measuring the effectiveness of foreign aid on GDP and government expenditure, linear regression model has applied assuming foreign aid independent variables and GDP and 
government expenditure as dependent variables.

The ultimate goal of foreign aid is to boost economic development in terms of GDP and government expenditure, keeping these in consideration the following model is specified to examine the effectiveness of foreign aid (Grants and Debt) on GDP and government expenditure:

$$
\begin{aligned}
& \mathrm{GDP}_{\mathrm{t}}=\alpha_{0}+\beta_{1} \mathrm{FA}+\beta_{2} \mathrm{FG}_{\mathrm{t}}+\varepsilon_{\mathrm{t}} \ldots \ldots \ldots \ldots \ldots \ldots \ldots \ldots \ldots \ldots \ldots \ldots \text { (i) } \\
& \mathrm{GEx}_{\mathrm{t}}=\alpha_{0}+\beta_{1} \mathrm{FA}+\beta_{2} \mathrm{FG}_{\mathrm{t}}+\varepsilon_{\mathrm{t}} \ldots \ldots \ldots \ldots \ldots \ldots \ldots \ldots \ldots \ldots \ldots \text { (ii) }
\end{aligned}
$$

Where, GDP is generated due to foreign aid (FA) and Government Expenditure (GEx) is also a component of foreign aid, grant and debt, FG is foreign grant. The $\alpha_{0}$ is constant, $\beta_{1}$ and $\beta_{2}$ are coefficients parameters. GDP is expected to be increase due to Foreign aid and Government expenditure is determined with the flow of foreign aid (Grants and Debt). The data are analyzed using SPSS and STAT-13 statistical software.

\section{RESULTS AND DISCUSSION}

\section{Evolution of Foreign Aid}

Nepal is one of the foreign aid recipient nations after 1952 when Nepal has joined the Colombo Plan for Cooperative, Economic and Social Development in Asia and Pacific. The development economic plan was set up via way of means of the British Commonwealth nations in 1951. Many of Nepalese obtained scholarships via the Colombo Plan for the research in technical and professional areas in different nations. During the 1950s, all foreign aid was provided in the form of grants where a significant assistance was allocated toward the development of agriculture, transportation, power production, infrastructure and other sector was assistance was targeted for the development of industry, education, health and communications as well. India and United States had taken responsibility for more than onethird of total grants where they established aid mission in Nepal and directed the aid in the special projects. The other donor countries were China and Soviet Union in that time. Besides this, Britain, Switzerland, Australia, Japan and New Zealand had also been additionally participated in support programs in addition to United Nations (UN) provided to technical assistance.

The scenery of foreign aid was mostly offered as per the bilateral basis where the Indian assistance was focused on constructing airport in Kathmandu, Koshi Dam including different irrigation projects in the mid of 1960s. Similarly, Soviet Union supported constructing cigarette 
and sugar factories, hydroelectric plant as well as East-West Highway. Chinese assistance was mobilized toward the construction of roads, trolley bus line, leather and shoe factory, brick and tile factories. Similarly, the American aid had focused on rural development, agriculture, schooling and public health in addition to granted loans to various industries.

The multilateral support programs had commenced within the 1970s which played a remarkable contribution in the development plans and accounted for greater than 70 percent of funding for development of planning in Nepal. By the end of the 1980s, a remarkable amount of foreign aid was received in terms of multilateral assistance programs. The foremost sources of borrowing or grants had been provided by the International Development Associations including the World Bank and Asian Development Bank. By 1987, 16 nations and 6 international agencies had been participated in that group. Most of development projects were funded with external help in concessional terms. More than 70 percent of aid was supported in terms of grants as well as concessional loans.

Nepal has been receiving foreign assistance in the form of commodity aid, technical assistance, project aid, as well as program support after 1990s. The project aid had focused on irrigation projects, roads and hydroelectric plants. The commodity support has emphasized on fertilizer, construction materials and seeds which were provided by the donor aid agencies. The technical support had focused on services of experts to advise the government in terms of training indigenous personnel to conduct research in technological areas and development of skilled labor as well as program aid assistance in health sector and agriculture.

\section{Priority Areas of Utilization of Foreign Grants}

The priority areas foreign grants were basically five major areas before 2010/11. The major segment of grants was on social services and second priority was on transportation, electricity and communication and the third priority areas was on agriculture, irrigation and forest sector. The industry and commerce sector was given insignificant priority. The priority areas of foreign grants was divided in different heads such as agriculture, irrigation and forest, transportation, electricity and communication, social services and others. 


\section{Figure 1}

Sector-wise Utilization of Foreign Grants from 1992/93 -2010/11

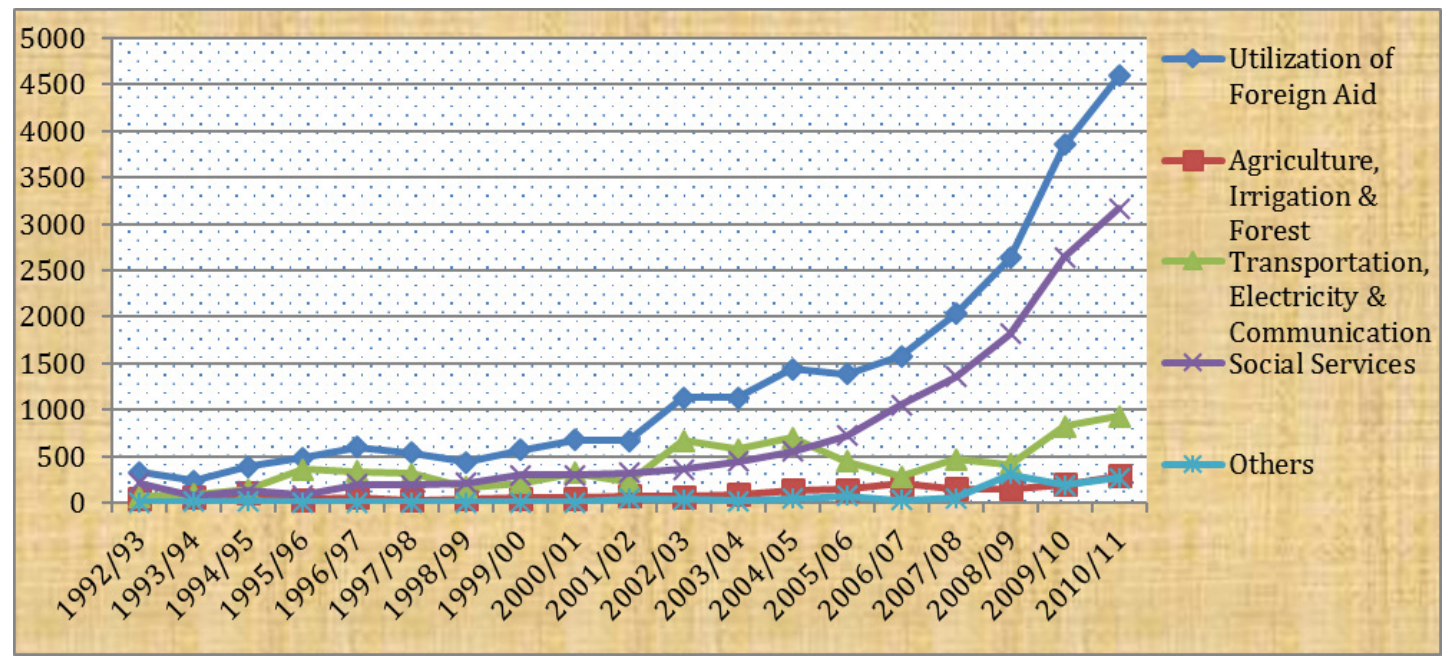

Source: Economic Survey 2010/11 \& 2011/12.

Figure-1 shows the status of priority areas of foreign grants from 1992/93 to 2010/11. The trends of total foreign grants of Nepal was increasing trends in that periods. Similarly, the trends of grants on priority areas were also increasing significantly in that time intervals, increasing trend of social services sector is more rapid than other. The priority areas of foreign grant have changed as per the areas of government expenditure after 2010/11.

\section{Table 1}

Sector-wise Utilization of Foreign Grants (2011-2019). (Rs. in Ten Million)

\begin{tabular}{|c|c|c|c|c|c|c|c|c|c|}
\hline Title/Year & $2011 / 12$ & 2012/13 & 2013/14 & $2014 / 15$ & 2015/16 & 2016/17 & 2017/18 & 2018/19 & $2019 / 20$ \\
\hline General public & 589.45 & 300.94 & 360.37 & 397.67 & 318.20 & 363.71 & 150.85 & 776.94 & 677.01 \\
\hline service & & & & & & & & & \\
\hline Defense & 0.00 & 0.00 & 19.22 & 17.46 & 0.00 & 0.00 & 0.00 & 0.00 & 0.00 \\
\hline $\begin{array}{l}\text { Public order \& } \\
\text { safety }\end{array}$ & 260.99 & 230.25 & 209.82 & 130.29 & 28.90 & 27.24 & 51.86 & 33.44 & 0.00 \\
\hline Economic affairs & 1140.11 & 1073.16 & 1542.04 & 1670.20 & 1522.74 & 2128.70 & 2775.31 & 904.71 & 782.02 \\
\hline environment & 4.05 & 1.83 & 46.62 & 94.74 & 179.51 & 127.74 & 153.74 & 155.96 & 120.33 \\
\hline $\begin{array}{l}\text { Conservation } \\
\text { housing \& }\end{array}$ & 291.27 & 205.11 & 218.01 & 152.34 & 157.24 & 242.63 & 198.46 & 74.55 & 185.62 \\
\hline $\begin{array}{l}\text { Community } \\
\text { facilities }\end{array}$ & & & & & & & & & \\
\hline Health & 570.03 & 568.28 & 503.72 & 403.74 & 494.59 & 745.57 & 294.55 & 291.42 & 445.01 \\
\hline
\end{tabular}




\begin{tabular}{llllllllll}
\hline $\begin{array}{l}\text { Entertainment, } \\
\text { Culture \& }\end{array}$ & 1.24 & 4.45 & 12.37 & 11.48 & 5.32 & 6.82 & 0.02 & 0.00 & 0.00 \\
$\begin{array}{l}\text { religion } \\
\text { Education }\end{array}$ & 1223.60 & 1137.28 & 1285.43 & 890.26 & 1149.79 & 394.91 & 292.60 & 46.29 & 109.40 \\
Social security & 0.28 & 1.69 & 22.98 & 60.40 & 97.91 & 44.60 & 14.49 & 6.56 & 2.18 \\
Total & 4081.03 & 3522.98 & 4220.58 & 3828.58 & 3954.40 & 4081.93 & 3931.87 & 2289.87 & 2321.57 \\
\hline
\end{tabular}

Source: Economic Survey 2019/20.

Table-1 depicts that the foreign grants of utilization from 2011/12 to 2019/20.The major focus has been given on economic affairs, the second priority has emphasized on education and third priority has given on health and general public service and so on. The chief priority was given basically economic affairs and education while utilization of grants.

\section{Figure 2}

Ratio of Foreign Debt, Foreign Grants and Assistance to Real GDP (at Basic Price-2000/21) of Nepal from 1992/93-2019/20.

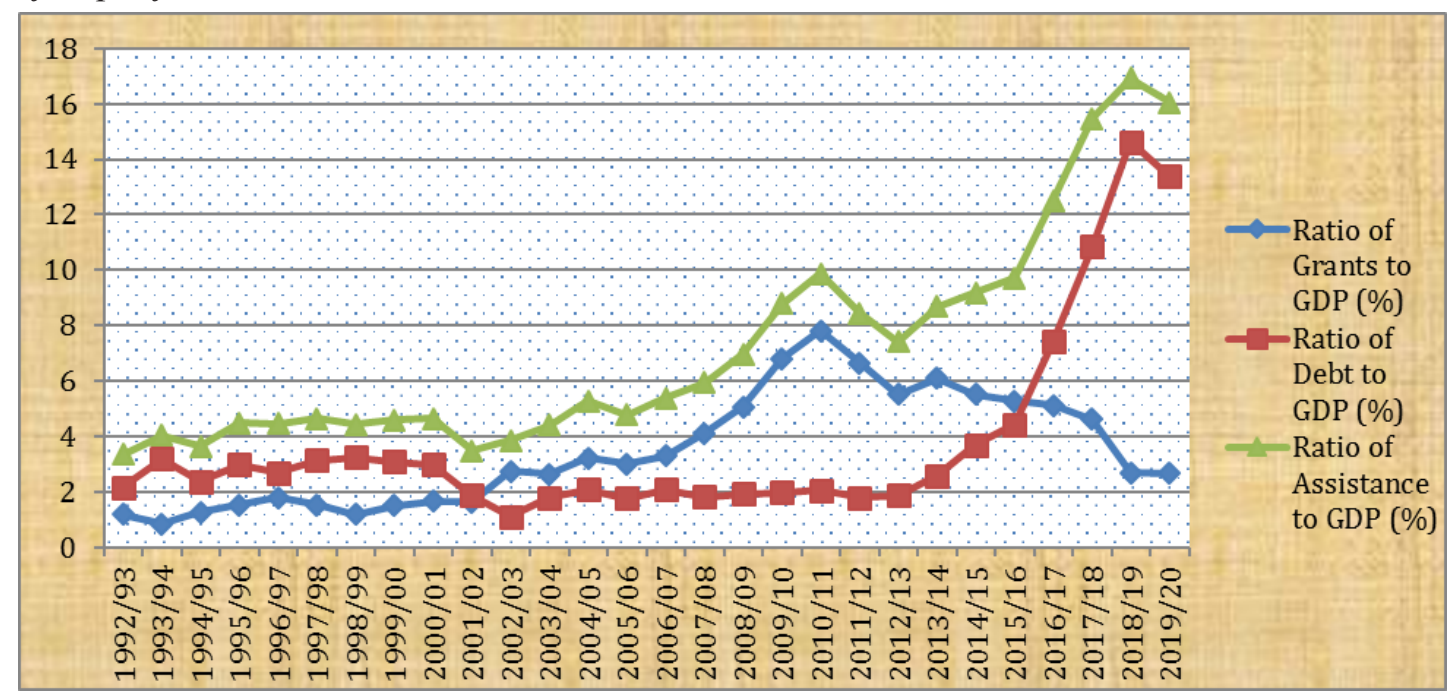

Source: MOF., Economic Survey (2010/11 \& 2019/20).

Figure-2 depicts the trend ratio of foreign grants, foreign debt and assistance to GDP and GDP growth rate from 1992/93 to 2019/20. The trend of assistance to GDP is continuously increase except fiscal year 2012/13. Similarly, ratio of foreign grand to GDP continuously increase up to FY 2011/12 and starts to decline. Ratio of foreign debt to GDP also seems to be increasing trend. The GDP growth rate trend is also fluctuating trends because the GDP growth is influenced by other socio-economic and political factors than identified given variables.

The multiple regression models have shown in the linear relation of independent variables 
with the given dependent variable to evaluate the units change in independent variables to the change in dependent variable. In this study, GDP has taken as a dependent variable in the first model whereas government expenditure has used as a dependent variable in the second model. The foreign aid and grants were assumed to explanatory variables. All independent variables in the models have found a positive impact on government expenditure and GDP. The value of $\mathrm{R}^{2}$ of this model estimation is received at 0.97 that represents $97 \%$ of the deviation in GDP which is explained by the variation of explanatory variables. This is statistically significant at 5 percent P-value (i.e. 0.000) which is fit in the model.

The result of regression represents the positive value of all coefficients of foreign aid which is significant. The coefficient of utilization of foreign aid has a positive and shows an increase in utilization of foreign aid brings increase in GDP. The coefficient indicates that 1-unit increase in utilization of foreign aid brings near about 21.57-unit increase in GDP per year. Similarly, the result of utilization of foreign grant has found a significant which brings in the change in GDP of a nation. The coefficient of utilization of foreign grants signifies that increase in foreign grants by one unit, increases the GDP by 12.54 units per year.

$$
\mathrm{GDP}_{\mathrm{t}}=\alpha_{0}+\beta_{1} \mathrm{FA}+\beta_{2} \mathrm{FG}_{\mathrm{t}}+\varepsilon_{\mathrm{t}} \text { and } \mathrm{GDP}_{\mathrm{t}}=-5,192+21.57 \mathrm{FA}+12.54 \mathrm{FG}+\varepsilon_{t}
$$

Table 2

Regression Analysis for Real GDP to Utilization of Foreign Aid and Utilization of Foreign Grant

\begin{tabular}{lllc}
\hline Variables & Coefficients & $\begin{array}{l}\text { Standard } \\
\text { Error }\end{array}$ & $\mathrm{t}$ - value \\
\hline Constant & -5.192 & 5.358 & -0.97 \\
Utilization of foreign aid (FA) & $21.57 * * *$ & 1.246 & 17.31 \\
Utilization of foreign grants (FG) & $12.54 * * *$ & 2.929 & 4.28 \\
\hline
\end{tabular}

Note: $* * * \mathrm{p}<0.01, * * \mathrm{p}<0.05, * \mathrm{p}<0.10$

Government Expenditure to Utilization of Foreign Aid and Utilization of Foreign Grant $\mathrm{GEx}_{\mathrm{t}}=\alpha_{0}+\beta_{1} \mathrm{FA}+\beta_{2} \mathrm{FG}_{\mathrm{t}}+\varepsilon_{\mathrm{t}}$ and $\mathrm{GEx}_{\mathrm{t}}=-7.075+8.620 \mathrm{FA}+-0.484 \mathrm{FG}+\varepsilon_{t}$ 
Table 3

Government Expenditure to Utilization of Foreign Aid and Utilization of Foreign Grant

\begin{tabular}{llll}
\hline Variables & Coefficients & \multicolumn{2}{l}{$\begin{array}{l}\text { Standard } \\
\text { Error }\end{array}$} \\
& & $\mathrm{t}$ - value \\
\hline Constant & $-7,075^{* * *}$ & 1,415 & -5.00 \\
Utilization of foreign aid (FA) & $8.620 * * *$ & 0.329 & 26.20 \\
Utilization of foreign grants (FG) & -0.484 & 0.773 & -0.63 \\
\hline
\end{tabular}

Note: $* * * \mathrm{p}<0.01, * * \mathrm{p}<0.05, * \mathrm{p}<0.10$.

From the second model, value of $\mathrm{R}^{2}$ estimation has found 0.98 that signifies $98 \%$ of the variation in the government expenditure which explained with the changes in the explanatory variables. As per the study, P-value (0.000) for overall fitness in this model is statistically significant even at one percent level of significant.

The regression result shows that the sign of utilization of foreign aid coefficient is positive and significant but the sign of utilization of foreign grand coefficient is negative and insignificant. The coefficient of utilization of foreign aid is positive which shows any increase in utilization of foreign aid brings increase in. government expenditure. The coefficient indicates that 1 unit increase in utilization of foreign aid brings near about 8.62 unit increase in government expenditure per year. Similarly, the result of utilization of foreign grand has insignificant which indicates that there is no any significance relation between utilization of foreign grand and government expenditure.

\section{CONCLUSION}

As per the study, foreign assistance is taken as the important components of social changes and economic progress with reference to Nepal. The trends of mobilization and utilization of foreign aid has been fluctuating nature and shifted from productive sector to service over the study periods. Foreign assistance does not contribute in GDP growth alone where the other socio-economic variables are responsible for influencing GDP. The major segment of grants was allocated on social services and economic services. The finding of the study shows that the coefficient of utilization of foreign aid was positive which shows any increase in utilization of foreign aid brings increase in GDP. Similarly, utilization of foreign grand has great significant which bringing change in GDP of a nation. However, the study shows that the result of utilization of foreign grand has insignificant which indicates that there is no any significance relation between utilization of foreign grand and government expenditure. This study argued that foreign aid mobilization effectiveness could be allocated 
in terms of changes in people's livelihood for the better progress. The good governance and political commitment and stability are the fundamental bases for effectiveness of utilization of foreign aid in Nepal.

\section{REFERENCES}

Action Aid. (2011). Real aid. 3. Ending aid dependency. Action Aid UK.

Adhikari, D. B (2018). Informal economy and poverty in urban Nepal. The Economic Journal of Nepal, 41(3 \& 4), 12-24.

Aime,H.R.(2010). Assessing the development role of foreign aid in developing countries: A special reference to the role of Japan's aid in far East Asia. V.R.F. Series No.462, Institute of Developing Economies, Japan External Trade Organization.

Bhattarai, B. P. (2007). Foreign aid and government's fiscal behavior in Nepal: An empirical analysis. Economic Analysis and Policy, 37(1), 41-60.

CBO. (1997). The role offoreign aid in development: A CBO study. The congress of the United States Congressional Budget Office, USA.

Chowdhury, A., \& Garonna, P. (2007). Effective foreign aid, economic integration and subsidiarity: Lessons from Europe. CASE Network studies and analyses, (346).

Gounder, R. (2003). A causality analysis of foreign aid and economic growth in the Solomon Islands. Pacific Economic Bulletin, 18 (1), 31-40.

Ministry of Finance (2002). Foreign aid policy, 2002. Ministry of Finance, Government Kathmandu, Nepal. Retrieved from foreign aid (mof.gov.np)

Ministry of Finance (2010), Economic survey, Government of Nepal 20110-11. Retrieved from mof.gov.np

Ministry of Finance (2011). Economic survey 2011/12. Government of Nepal. Retrieved from Economic Survey 2011-12_20141224054554.pdf (mof.gov.np)

Ministry of Finance (2017). A Study on foreign aid mobilization in federal Nepal. Government of Nepal. Retrieved from Federal Study_20190204051241.pdf (mof.gov.np)

Ministry of Finance (2019), Economic survey. Government of Nepal. Retrieved from Economic Survey 2019_20201125024153.pdf(mof.gov.np)

Murshed, M., \& Khanaum, M. M. (2014). Impact of foreign aid in the economic development of recipient country. Journal of the Bangladesh Association of Young Researchers, 2(1), 33-37.

De Renzio, P. (2016). Accountability dilemmas in foreign aid. Overseas Development Institute. 
Gulrajani, N., \& Calleja, R. (2019). Understanding donor motivations: Developing the principled aid index. Working Paper 546. Overseas Development Institute.

Karki, Y., \& Pappas, I.O. (2020). Investing aid effectiveness in developing countries: The case of Nepal. Springer Nature. https://doi.org/10.1007/978-3-030-45002-1_29

Paul, E. (2006). A survey of the theoretical economic literature on foreign aid. Asian Pacific Economic Literature, 20 (1),1-17.

Pradhan, C. \& Phuyal, R.K. (2020). Impact of foreign aid on economic growth of Nepal: An empirical evidence. International Journal and Banking Research, 6(3), 44-50.

Hannemann, W.H., \& Schneider, F. (1988). Determinants of foreign aid under alternative institutional arrangements (No. 66). Diskussionsbeiträge-Serie II.

Werker, E., Ahmed, F. Z., \& Cohen, C. (2009). How is foreign aid spent? Evidence from a natural experiment. American Economic Journal of Macroeconomics, 1(2), 225-44. 